\title{
Obituary for Edith Blumhofer (April 24, 1950-March 5, 2020)
}

Edith Blumhofer, Emerita Professor of History at Wheaton College (Wheaton, IL), died March 5, 2020 at age 69. She is survived by her husband Edwin of 44 years, three children, and six grandchildren. She earned her $\mathrm{PhD}$ from Harvard University (1977). In 2009 Blumhofer joined the Board of Trustees of the Overseas Ministries Study Center (OMSC), which publishes the International Bulletin of Mission Research. She was elected its president in 2014 and oversaw leadership and staff changes and its eventual move from New Haven, CT, to Princeton Seminary in 2020. She was a prolific author and scholar of American religious history, writing on Pentecostalism in American culture, including biographies of Aimee Semple McPherson and Fanny J. Crosby. She co-authored or edited more than a dozen additional books and was especially interested in hymns and the history of Protestant hymnody. She also published articles in the Wall Street Journal, The Christian Century, and Christianity Today. At Wheaton she directed the Institute for the Study of American Evangelicals (1999-2014). Readers of Mission Studies will be interested to learn of her research and writing on the foreign missions movement and its impact on North American society and culture. In addition to these accomplishments, Blumhofer was a well-rounded individual with many gifts and graces. She was known as an accomplished cook and great baker; a lover of music as a singer, pianist, and trumpeter; a treasured professor, mentor, and colleague; and a good friend to many.

Darrell Whiteman

Global Development, Gig Harbor, WA, USA 